\title{
Endogenous flow of amino acids in the avian ileum as influenced by increasing dietary peptide concentrations
}

\author{
Velmurugu Ravindran*, Patrick C. H. Morel, Shane M. Rutherfurd and Donald V. Thomas \\ Institute of Food, Nutrition and Human Health, Massey University, Palmerston North, New Zealand
}

(Received 22 January 2008 - Revised 6 May 2008 - Accepted 17 June 2008 - First published online 29 July 2008)

The aim of the present study was to establish whether feeding broiler chickens with diets containing increasing dietary peptide concentrations would cause increases in ileal endogenous amino acid flow. The flow of $\mathrm{N}$ and most amino acids increased quadratically $(P<0 \cdot 05$ to $0 \cdot 001)$ with increasing dietary concentrations of peptides. The exceptions were the flow of threonine, serine, glycine, tyrosine and cystine, which increased linearly $(P<0.001)$ with dietary peptide levels. Another notable exception to the general trend was the flow of proline, which was significantly higher $(P<0.01)$ in birds fed the protein-free diet. The amino acid profile of endogenous protein, expressed as proportion of crude protein, indicated that the ratios of threonine, glutamic acid, proline, glycine, leucine, histidine, arginine and cystine were influenced $(P<0.05)$ with increasing dietary peptide concentrations. In general, compared with the protein-free diet, the ratios of threonine and arginine in endogenous protein were lower $(P<0.05)$ and those of glutamic acid, glycine and histidine were greater $(P<0.05)$ in diets with high concentrations of peptides. The ratio of proline was found to decrease $(P<0.05)$ with increasing dietary peptide concentrations. These changes in the amino acid profile of endogenous protein are probably reflective of changes in the output of one or more of the components of endogenous protein. Overall, the present results demonstrated that increasing dietary peptide concentrations increased the flow of endogenous amino acid flow at the terminal ileum of broiler chickens in a dose-dependent manner and also caused changes in the composition of endogenous protein. The observed changes in endogenous amino flow will influence the maintenance requirements for amino acids and also have implications for the calculation of true digestibility coefficient of feedstuffs.

Ileal endogenous amino acid flow: Enzyme-hydrolysed casein: Chickens

During the digestion and absorption of ingested feed, significant amounts of endogenous $\mathrm{N}$ enter the gastrointestinal tract at various segments. These inevitable secretions containing $\mathrm{N}$ predominantly originate from various digestive secretions, mucoproteins and desquamated epithelial cells lining the gut $^{(1,2)}$. A proportion of these secretions escapes digestion and re-absorption and amino acids (AA) ${ }^{(2)}$ from endogenously secreted proteins that reach the terminal ileum are lost to the animal. Reliable estimates of these losses of $\mathrm{N}$ and AA are necessary for the calculation of true digestibility values of feed ingredients and for the determination of AA requirements by the factorial method. The true ileal AA digestibility of an ingredient is a better measure than apparent digestibility because it represents the AA actually released from dietary protein and absorbed by the animal, and yields more precise estimates of the amount of AA provided in a mixed diet.

In poultry, the endogenous flow of AA has traditionally been determined by the measurement of AA excretion at the excreta level in fasted birds or in birds fed on protein-free $\operatorname{diets}^{(3)}$. Both these conditions are physiologically abnormal and could influence body protein catabolism and digestive enzyme secretions in the gut. Furthermore, AA that disappear post-ileum are not considered beneficial to chickens because their disappearance is due to hindgut microbial action and not absorption ${ }^{(4)}$. Thus AA digestibility must be measured at the terminal ileum rather than in the excreta ${ }^{(5)}$ and it is the endogenous AA flow at the ileal level that should be considered as true losses to the animal.

An approach that overcomes the limitations of the traditional methods and that can be used for routine determination of ileal endogenous AA flow under conditions of peptide alimentation was proposed by Moughan et al. ${ }^{(6)}$. In this method, the animal is fed a purified diet containing enzyme-hydrolysed casein (EHC) as the sole $\mathrm{N}$ source. The hydrolysed casein consists of small peptides and free AA (molecular weight $<5000 \mathrm{Da}$ ), which act to maintain physiologically normal levels of endogenous $\mathrm{N}$ flow throughout the intestinal tract. Ileal digesta are collected, centrifuged and the supernatant fraction is ultrafiltered (exclusion limit, molecular weight $10000 \mathrm{Da}$ ). The precipitate from the centrifugation step and the retentate from the ultrafiltration step $(>10000 \mathrm{Da})$ are assumed to represent the endogenous component of the digesta. This method has been used to measure ileal AA losses in pigs ${ }^{(7-10)}$, in rats ${ }^{(11)}$ and in chickens ${ }^{(12,13)}$.

Studies comparing protein-free and EHC diets have shown that the presence of dietary peptides results in marked increases in the endogenous flow of $\mathrm{N}$ and $\mathrm{AA}^{(1,13-15)}$. 
The effect of only a single inclusion level of EHC was tested in these studies and it is not known whether this is a one-off effect or whether the inclusion of graded levels of dietary peptides would cause gradual increases in ileal endogenous flows of $\mathrm{N}$ and AA. A study by Hodgkinson et al. ${ }^{(10)}$, with pigs, showed that ileal endogenous AA flow increased when dietary EHC concentrations were increased from 0 to $200 \mathrm{~g} / \mathrm{kg}$. In contrast, using guanidinated soyabean meal, Zhang et al. ${ }^{(16)}$ found that increasing the dietary protein content from 100 to $250 \mathrm{~g} / \mathrm{kg}$ had no effect on the ileal endogenous flow of lysine in growing pigs. The aim of the present study was to examine the effects of graded dietary concentrations of EHC on the endogenous AA flow in the avian ileum.

\section{Materials and methods}

\section{Diets}

Six diets were formulated. These included a basal diet and five test diets that contained 0 (protein-free diet), 50, 100, 150 and $200 \mathrm{~g} \mathrm{EHC} / \mathrm{kg}$ (Table 1). In the latter four diets, EHC served as the sole source of $\mathrm{N}$. Titanium oxide $(3 \mathrm{~g} / \mathrm{kg})$ was included in all test diets as an inert digesta marker for the calculation of endogenous AA flows. The basal diet was similar to the EHC diet except that casein was used in place of EHC and that no titanium oxide was included.

\section{Birds}

Male broiler (Ross 308) chicks were obtained at $1 \mathrm{~d}$ of age from a commercial hatchery and raised in floor pens as per standard commercial practice. The birds were fed a commercial starter diet, in mash form, based on wheat, soya and meat meal (12.6 MJ metabolisable energy $/ \mathrm{kg}, 236 \mathrm{~g}$ crude protein $/ \mathrm{kg}, 96 \mathrm{~g} \mathrm{Ca} / \mathrm{kg}$ and $48 \mathrm{~g}$ available $\mathrm{P} / \mathrm{kg}$ ) till $21 \mathrm{~d}$ of age. On day 21 post-hatching, the birds were individually weighed and eighty birds (average weight $880 \mathrm{~g}$ ) were selected and assigned to twenty cages of four birds each. The five dietary treatments were then randomly assigned to four cages each.

The cages were housed in an environmentally controlled room with $24 \mathrm{~h}$ fluorescent lighting. Room temperature was maintained at $24 \pm 2^{\circ} \mathrm{C}$ during the assay. The experimental procedures were approved by the Animal Ethics Committee of Massey University.

\section{Conduct of the trial}

From age $21 \mathrm{~d}$ to $28 \mathrm{~d}$, the birds were first trained to consume a mash diet, which was made by grinding commercial starter pellets in a hammer-mill to pass through a $3 \mathrm{~mm}$ screen. After 1 week on the mash diet, the basal diet was gradually introduced. The aim of using the casein-based basal diet was to enable the birds to get adjusted to the changeover to purified diets. The basal diet was withdrawn after $4 \mathrm{~d}$ and the test diet containing EHC was introduced on day 32 post-hatch. The diets were offered ad libitum and water was available at all times.

\section{Digesta collection and processing}

After $4 \mathrm{~d}$ on the EHC diet, the birds were euthanised by an intracardial injection of sodium pentabarbitone, and the contents of the lower half of the ileum were collected by gently flushing with distilled water into plastic containers. The ileum was defined as that portion of the small intestine extending from Meckel's diverticulum to a point $40 \mathrm{~mm}$ proximal to the ileocaecal junction. Samples from birds within a pen were pooled, homogenised, frozen immediately after collection and lyophilised $^{(17)}$.

The following procedure ${ }^{(15)}$ was used to separate the endogenous protein fraction in the ileal digesta of birds fed the EHC diets. The lyophilised samples were re-suspended in deionised water and acidified to $\mathrm{pH} 3.5$ with $9 \mathrm{M}-\mathrm{H}_{2} \mathrm{SO}_{4}$. The samples were stored overnight at $4{ }^{\circ} \mathrm{C}$ and then centrifuged

Table 1. Composition $(\mathrm{g} / \mathrm{kg})$ of the basal diet, protein-free diet and the test diets containing graded levels of enzyme-hydrolysed casein (EHC)

\begin{tabular}{|c|c|c|c|c|c|c|}
\hline & \multicolumn{6}{|c|}{ Diet } \\
\hline & Basal $^{*}$ & Protein-free & $50 \mathrm{~g} \mathrm{EHC} / \mathrm{kg}$ & $100 \mathrm{~g} \mathrm{EHC} / \mathrm{kg}$ & $150 \mathrm{~g} \mathrm{EHC} / \mathrm{kg}$ & $200 \mathrm{~g} \mathrm{EHC} / \mathrm{kg}$ \\
\hline Casein & 180 & - & - & - & - & - \\
\hline $\mathrm{EHC} \dagger$ & - & - & 50 & 100 & 150 & 200 \\
\hline Dextrose & 670 & 847 & 797 & 747 & 697 & 647 \\
\hline Vegetable oil & 50 & 50 & 50 & 50 & 50 & 50 \\
\hline Cellulose & 35 & 35 & 35 & 35 & 35 & 35 \\
\hline Dicalcium phosphate & 24 & 24 & 24 & 24 & 24 & 24 \\
\hline Sodium bicarbonate & 20 & 20 & 20 & 20 & 20 & 20 \\
\hline $\mathrm{K}_{2} \mathrm{HPO}_{4}$ & 12 & 12 & 12 & 12 & 12 & 12 \\
\hline Salt & 4 & 4 & 4 & 4 & 4 & 4 \\
\hline Titanium oxide & - & 3 & 3 & 3 & 3 & 3 \\
\hline $\mathrm{MgO}$ & 2 & 2 & 2 & 2 & 2 & 2 \\
\hline Mineral premix $\ddagger$ & 2.5 & 2.5 & 2.5 & 2.5 & 2.5 & $2 \cdot 5$ \\
\hline Vitamin premix§ & 0.5 & 0.5 & 0.5 & 0.5 & 0.5 & 0.5 \\
\hline
\end{tabular}

* The basal diet was fed to all birds for $4 \mathrm{~d}$ before the introduction of the $\mathrm{EHC}$ diet.

† New Zealand Pharmaceuticals Ltd (Palmerston North, New Zealand). The molecular-weight distribution was determined using gel permeation chromatography. All samples were less than $5000 \mathrm{Da}$ in size, with $99 \%$ less than $3000 \mathrm{Da}$.

‡ Supplied (per kg diet): Mn, $125 \mathrm{mg} ; \mathrm{Zn}, 60 \mathrm{mg}$; Cu, $3 \mathrm{mg}$; Mo, 0.5 mg; Co, 0.3 mg; I, 1 mg; Fe, $25 \mathrm{mg}$; Se, $200 \mu \mathrm{g}$; choline chloride, $638 \mathrm{mg}$.

$\S$ Supplied (per kg diet): trans-retinol, $3.33 \mathrm{mg}$; cholecalciferol, $60 \mu \mathrm{g}$; dl- $\alpha$-tocopheryl acetate, $60 \mathrm{mg} ; \mathrm{menadione,} 4 \mathrm{mg}$; thiamine, $3.0 \mathrm{mg}$; riboflavin, $12 \mathrm{mg}$; calcium pantothenate, $12.8 \mathrm{mg}$; niacin, $35 \mathrm{mg}$; pyridoxine, $10 \mathrm{mg}$; folic acid, $5.2 \mathrm{mg}$; cyanocobalamin, $0.017 \mathrm{mg}$; biotin, $0.2 \mathrm{mg}$; antioxidant, $100 \mathrm{mg}$. 
at $1450 \mathrm{~g}$ for $45 \mathrm{~min}$ at $0^{\circ} \mathrm{C}$. The supernatant fraction was decanted off and retained. The precipitate was washed with $10 \mathrm{ml}$ deionised water and centrifuged at $1450 \mathrm{~g}$ for $30 \mathrm{~min}$ at $0^{\circ} \mathrm{C}$. The second supernatant fraction was added to the first and the precipitate was stored at $-20^{\circ} \mathrm{C}$. The combined supernatant fractions were ultrafiltered using a Centriprep-10 ultrafiltering device (molecular weight cut-off filter, $10000 \mathrm{Da}$; Amicon Inc., Beverly, MA, USA) according to the manufacturer's instructions. The precipitate from the centrifugation step was added to the retentate $(>10000 \mathrm{Da})$ from the ultrafiltration step, and the material was lyophilised.

Diet and dried ileal digesta samples were then ground to pass through a $0.5 \mathrm{~mm}$ sieve and stored in airtight containers at $-4^{\circ} \mathrm{C}$ for chemical analyses.

\section{Chemical analyses}

The diets, digesta samples from birds fed the protein-free diet and ultrafiltered ileal digesta samples from birds fed the EHC diets were analysed for DM, N, AA and titanium as described below.

DM determination was carried out according to standard procedures $^{(18)}$. Total $\mathrm{N}$ was determined following Kjeldahl digestion by colorimetric auto-analyser ${ }^{(19)}$. AA were determined by hydrolysing the samples with $\mathrm{HCl}$ (containing phenol) for $24 \mathrm{~h}$ at $110 \pm 2{ }^{\circ} \mathrm{C}$ in glass tubes sealed under vacuum. AA were detected on a Waters ion exchange HPLC system, and the chromatograms were integrated using dedicated software (Millenium 32; Waters, Millipore, Milford, MA, USA) with the AA identified and quantified using a standard AA solution (Pierce, Rockford, IL, USA). Cystine and methionine were analysed as cysteic acid and methionine sulfone by oxidation with performic acid for $16 \mathrm{~h}$ at $0^{\circ} \mathrm{C}$ and neutralisation with hydrobromic acid before hydrolysis. Tryptophan was not determined. Titanium content was measured on a UV spectrophotometer following the method of Short et al. ${ }^{(20)}$.

\section{Calculations}

The flow of $\mathrm{N}$ and individual $\mathrm{AA}$ at the terminal ileum was calculated, as mg lost per $\mathrm{kg}$ ingested feed DM, using the following formula and these values were considered to be the estimate for endogenous flow ${ }^{(21)}$.

$$
\begin{aligned}
& \text { Endogenous N or AA flow (mg/kg DM intake) } \\
& =\mathrm{N} \text { or AA concentration in ileal digesta }(\mathrm{mg} / \mathrm{kg}) \\
& \times(\text { diet titanium }(\mathrm{mg} / \mathrm{kg}) / \text { ileal digesta titanium }(\mathrm{mg} / \mathrm{kg})) \text {. }
\end{aligned}
$$

The AA profile of endogenous protein $(\mathrm{N} \times 6.25)$ was calculated by expressing each AA as a percentage of endogenous crude protein.

\section{Statistical analysis}

The data were tested for homogeneity of variance using Bartlett's test ${ }^{(22)}$. The statistical analyses used the general linear models procedure of SAS (SAS Institute, Inc., Cary, $\mathrm{NC}$, USA) ${ }^{(23)}$ with pen means as the experimental unit. Where appropriate, significant differences between means were separated using the least significance difference test. Linear and quadratic effects of graded dietary levels of EHC $(0,50,100,150$ and $200 \mathrm{~g} / \mathrm{kg})$ on endogenous flow of $\mathrm{N}$ and AA were tested with orthogonal polynomials ${ }^{(23)}$.

\section{Results}

During the $4 \mathrm{~d}$ assay period, feed intake was similar $(P>0.05)$ between the dietary treatments. Average daily feed intake of birds fed diets containing 0, 50, 100, 150 and $200 \mathrm{~g} \mathrm{EHC/kg}$ were $65,70,78,74$ and 68 (SEM 4.5) g/bird, respectively.

The determined crude protein and AA contents of the test diets are shown in Table 2. The ileal endogenous flows of $\mathrm{N}$ and $\mathrm{AA}$ in birds fed diets containing graded concentrations of EHC are summarised in Table 3. The flows of $\mathrm{N}$ and most AA

\begin{tabular}{|c|c|c|c|c|c|}
\hline & \multicolumn{5}{|c|}{ Diet } \\
\hline & Protein-free & $50 \mathrm{~g} \mathrm{EHC} / \mathrm{kg}$ & $100 \mathrm{~g} \mathrm{EHC} / \mathrm{kg}$ & $150 \mathrm{~g} \mathrm{EHC} / \mathrm{kg}$ & $200 \mathrm{~g} \mathrm{EHC} / \mathrm{kg}$ \\
\hline Crude protein $(\mathrm{N} \times 6.25)$ & 3.88 & $48 \cdot 2$ & $92 \cdot 6$ & 145.5 & $198 \cdot 4$ \\
\hline Aspartic acid & $0 \cdot 17$ & 3.55 & 7.56 & $10 \cdot 70$ & 14.74 \\
\hline Threonine & 0.06 & 1.79 & 3.44 & $5 \cdot 32$ & $7 \cdot 21$ \\
\hline Serine & 0.07 & $2 \cdot 34$ & $4 \cdot 36$ & $7 \cdot 16$ & $9 \cdot 20$ \\
\hline Glutamic acid & 0.26 & $10 \cdot 40$ & 19.90 & 31.35 & $42 \cdot 10$ \\
\hline Proline & 0.00 & 4.89 & $9 \cdot 25$ & 14.69 & $19 \cdot 62$ \\
\hline Glycine & 0.12 & 0.94 & 1.64 & 2.58 & 3.45 \\
\hline Alanine & 0.12 & 1.42 & 2.45 & 3.91 & 5.34 \\
\hline Valine & $0 \cdot 10$ & 2.92 & 5.56 & 8.63 & $11 \cdot 32$ \\
\hline Isoleucine & 0.12 & $2 \cdot 36$ & 4.59 & 6.99 & $9 \cdot 40$ \\
\hline Leucine & $0 \cdot 17$ & 4.28 & 8.35 & $12 \cdot 78$ & $17 \cdot 45$ \\
\hline Tyrosine & 0.07 & 0.98 & 1.85 & 3.02 & 4.00 \\
\hline Phenylalanine & 0.07 & $2 \cdot 19$ & 4.34 & $7 \cdot 22$ & 9.47 \\
\hline Histidine & $0 \cdot 14$ & 1.42 & 2.58 & $4 \cdot 16$ & $5 \cdot 45$ \\
\hline Lysine & $0 \cdot 16$ & $3 \cdot 71$ & 7.04 & $10 \cdot 66$ & 14.52 \\
\hline Arginine & 0.08 & 1.37 & 2.92 & 4.88 & $6 \cdot 30$ \\
\hline Methionine & 0.00 & 0.84 & 0.87 & 0.96 & $1 \cdot 13$ \\
\hline Cystine & 0.00 & 1.59 & 2.91 & 4.89 & 5.92 \\
\hline
\end{tabular}

Table 2. Determined crude protein and amino acid concentrations ( $/ \mathrm{kg} \mathrm{DM})$ of the protein-free diet and the test diets containing graded levels of enzyme-hydrolysed casein (EHC) 
Table 3. Ileal endogenous flows ( $\mathrm{mg} / \mathrm{kg}$ DM intake) in 5-week-old broiler chickens fed diets containing graded levels of enzyme-hydrolysed casein (EHC) (Mean values for four replicates of five birds each with their pooled standard errors)

\begin{tabular}{|c|c|c|c|c|c|c|c|c|}
\hline & \multicolumn{5}{|c|}{ Diet } & \multirow[b]{2}{*}{ SEM } & \multicolumn{2}{|c|}{ Significance } \\
\hline & Protein-free diet & $50 \mathrm{~g} \mathrm{EHC} / \mathrm{kg}$ & $100 \mathrm{~g} \mathrm{EHC} / \mathrm{kg}$ & $150 \mathrm{~g} \mathrm{EHC} / \mathrm{kg}$ & $200 \mathrm{~g} \mathrm{EHC} / \mathrm{kg}$ & & Linear & Quadratic \\
\hline $\mathrm{N}$ & 1232 & 1311 & 1733 & 2096 & 2722 & $106 \cdot 3$ & 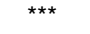 & *** \\
\hline Aspartic acid & 549 & 674 & 887 & 1050 & 1345 & $45 \cdot 5$ & $\star \star \star *$ & NS \\
\hline Threonine & 527 & 583 & 776 & 886 & 1037 & 59.9 & $\star \star \star ~$ & NS \\
\hline Serine & 414 & 522 & 611 & 727 & 972 & $55 \cdot 9$ & 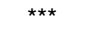 & NS \\
\hline Glutamic acid & 689 & 903 & 1170 & 1941 & 2485 & $84 \cdot 0$ & 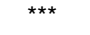 & NS \\
\hline Proline & 1070 & 561 & 595 & 590 & 706 & 44.8 & * & * \\
\hline Glycine & 477 & 698 & 868 & 1011 & 1461 & $65 \cdot 1$ & *** & NS \\
\hline Alanine & 292 & 351 & 327 & 484 & 606 & 31.8 & $\star \star \star ~$ & ** \\
\hline Valine & 282 & 346 & 485 & 614 & 831 & 39.7 & 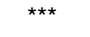 & ** \\
\hline Isoleucine & 252 & 246 & 342 & 422 & 573 & 30.5 & *** & ** \\
\hline Leucine & 363 & 350 & 619 & 702 & 1002 & 58.0 & $\star \star \star *$ & ** \\
\hline Tyrosine & 206 & 192 & 285 & 326 & 395 & $20 \cdot 8$ & $\star \star \star ~$ & * \\
\hline Phenylalanine & 195 & 231 & 238 & 320 & 401 & $20 \cdot 4$ & $\star \star \star ~$ & ** \\
\hline Histidine & 133 & 123 & 243 & 298 & 379 & $18 \cdot 9$ & *** & ** \\
\hline Lysine & 225 & 251 & 343 & 464 & 579 & 33.8 & *** & ** \\
\hline Arginine & 238 & 245 & 281 & 321 & 404 & $28 \cdot 1$ & $\star \star \star ~$ & ** \\
\hline Methionine & 89 & 109 & 120 & 151 & 202 & $16 \cdot 2$ & $\star \star \star *$ & ** \\
\hline Cystine & 201 & 235 & 263 & 295 & 355 & $13 \cdot 4$ & *** & NS \\
\hline Sum of amino acids & 6201 & 6619 & 8452 & 10603 & 13753 & $310 \cdot 1$ & $\star \star \star ~$ & ** \\
\hline Amino acid-N & 922 & 968 & 1220 & 1540 & 1990 & 44.5 & *** & ** \\
\hline Amino acid- $\mathrm{N}$, as \% total $\mathrm{N}$ & $75 \cdot 0$ & 73.9 & $70 \cdot 6$ & 73.6 & $73 \cdot 1$ & 1.61 & NS & NS \\
\hline
\end{tabular}

${ }^{\star} P<0.05,{ }^{* *} P<0.01,{ }^{* * *} P<0.001$.

increased quadratically ( $P<0.05$ to 0.001$)$ with increasing dietary levels of EHC. The exceptions were the flows of aspartic acid, threonine, serine, glutamic acid, glycine and cystine, which increased linearly $(P<0.001)$ with dietary EHC levels. The flow of proline was another exception and this was markedly higher in birds fed the protein-free diet and unaffected when dietary EHC levels were increased from 50 to $200 \mathrm{~g} / \mathrm{kg}$. In general, the flow of $\mathrm{N}$ and individual AA (except that of proline) determined for the protein-free diet and the $50 \mathrm{~g} \mathrm{EHC} / \mathrm{kg}$ diet were similar, but the flow increased when the EHC was included at or above $100 \mathrm{~g} / \mathrm{kg}$. The ileal flow of $\mathrm{N}$ and total AA in birds fed the $200 \mathrm{~g} \mathrm{EHC} / \mathrm{kg}$ diet were $2 \cdot 2$-fold greater than those determined for the protein-free diet, except for proline. The flow of individual AA in birds fed the $200 \mathrm{~g} / \mathrm{kg}$ diet ranged from 1.8 (cystine) to 3.6 (glutamic acid) times higher than those fed the protein-free diet.

Glutamic acid was the most abundant AA in the endogenous flow (Tables 3 and 4). Other AA that were present in relatively high concentrations were glycine, threonine, aspartic acid, serine, valine and isoleucine. Concentration of methionine was the lowest.

The AA profile of endogenous protein, expressed as a proportion of crude protein, indicates that threonine, glutamic acid, proline, glycine, leucine, histidine, arginine and cystine ratios were influenced $(P<0.05)$ by dietary treatments (Table 4). In general, compared with the protein-free diet, the proportions of threonine and arginine in endogenous protein were lower $(P<0 \cdot 05)$ and those of glutamic acid, glycine and histidine were greater $(P<0.05)$ in diets with $200 \mathrm{~g} \mathrm{EHC/}$ $\mathrm{kg}$. Increasing the dietary EHC concentration from 50 to $200 \mathrm{~g} / \mathrm{kg}$ had no effect $(P>0.05)$ on the ratio of most AA in the endogenous protein. The exceptions were glutamic acid, proline, histidine and cystine. The ratios of proline and cystine were found to decrease $(P<0.05)$ with increasing dietary $\mathrm{EHC}$ concentrations, while those of glutamic acid and histidine were greater $(P<0 \cdot 05)$ at higher inclusions of EHC.

\section{Discussion}

The aim of the present study was to investigate whether increasing dietary concentration of peptides will cause increased flow of endogenous protein and AA in the avian ileum. The results showed that the endogenous flow of the $\mathrm{N}$ and total AA were found to be similar between the protein-free diet and the $50 \mathrm{~g} \mathrm{EHC/kg} \mathrm{diet,} \mathrm{but} \mathrm{increased}$ when the dietary EHC was included at or above $100 \mathrm{~g} / \mathrm{kg}$. Compared with the protein-free diet, the inclusion of 50 , 100,150 and $200 \mathrm{~g} \mathrm{EHC} / \mathrm{kg}$ increased the mean endogenous $\mathrm{N}$ flow by $6.4,40 \cdot 7,70 \cdot 1$ and $120.9 \%$, respectively. The corresponding increases in the flow of total AA were found to be $6 \cdot 7,36 \cdot 3,71 \cdot 0$ and $121.8 \%$, respectively.

Constant endogenous AA values are commonly employed in corrections in the conversion of apparent digestibility coefficients to true digestibility coefficients, as it is generally assumed that dietary protein concentration has no effect of endogenous AA flow at the terminal ileum. The present results show that such an approach to calculate true AA digestibility coefficients of feedstuffs or diets with varying protein concentrations is not valid and that changes in endogenous AA flow with dietary protein concentrations need to be considered in true digestibility calculations.

It appeared that an EHC concentration of $50 \mathrm{~g} / \mathrm{kg}$ was insufficient to have a significant effect on the ileal endogenous AA flow. In general, the endogenous flow of AA, with the exception of proline, followed the same pattern. The response of individual AA to increasing peptide concentrations, however, was varied. Compared with the flow in birds fed the $50 \mathrm{~g} \mathrm{EHC} / \mathrm{kg}$ diet, the increments in those fed the $200 \mathrm{~g} \mathrm{EHC} / \mathrm{kg}$ diet were 
Table 4. Amino acid composition of endogenous protein ( $\mathrm{g} / \mathrm{kg}$ crude protein) in broilers fed the protein-free diet and test diets containing graded levels of enzyme-hydrolysed casein (EHC)

(Mean values for four replicates of five birds each with their pooled standard errors)

\begin{tabular}{lcccccc}
\hline \multicolumn{5}{c}{ Diet } \\
\cline { 2 - 5 } & Protein-free diet & $50 \mathrm{~g} \mathrm{EHC} / \mathrm{kg}$ & $100 \mathrm{~g} \mathrm{EHC} / \mathrm{kg}$ & $150 \mathrm{~g} \mathrm{EHC} / \mathrm{kg}$ & $200 \mathrm{~g} \mathrm{EHC} / \mathrm{kg}$ & SEM \\
\hline Aspartic acid & $71 \cdot 7$ & $82 \cdot 3$ & $82 \cdot 0$ & $80 \cdot 3$ & $79 \cdot 0$ & $4 \cdot 8$ \\
Threonine & $68 \cdot 8^{\mathrm{a}, \mathrm{b}}$ & $71 \cdot 1^{\mathrm{a}}$ & $71 \cdot 9^{\mathrm{a}}$ & $67 \cdot 5^{\mathrm{a}, \mathrm{b}}$ & $60 \cdot 8^{\mathrm{b}}$ & $3 \cdot 3$ \\
Serine & $53 \cdot 8$ & $63 \cdot 7$ & $56 \cdot 4$ & $55 \cdot 2^{\mathrm{b}}$ & $57 \cdot 0$ & $4 \cdot 3$ \\
Glutamic acid & $90 \cdot 0^{\mathrm{b}}$ & $110 \cdot 2^{\mathrm{b}}$ & $108 \cdot 2^{\mathrm{b}}$ & $148 \cdot 4^{\mathrm{a}}$ & $146 \cdot 1^{\mathrm{a}}$ & $6 \cdot 5$ \\
Proline & $139 \cdot 6^{\mathrm{a}}$ & $68 \cdot 6^{\mathrm{b}}$ & $55 \cdot 2^{\mathrm{b}, \mathrm{c}}$ & $45 \cdot 2^{\mathrm{c}}$ & $41 \cdot 5^{\mathrm{c}}$ & $7 \cdot 9$ \\
Glycine & $61 \cdot 4^{\mathrm{b}}$ & $85 \cdot 2^{\mathrm{a}}$ & $80 \cdot 5^{\mathrm{a}}$ & $77 \cdot 4^{\mathrm{a}, \mathrm{b}}$ & $85 \cdot 8^{\mathrm{a}}$ & $5 \cdot 8$ \\
Alanine & $37 \cdot 7$ & $42 \cdot 9$ & $31 \cdot 3$ & $37 \cdot 0$ & $35 \cdot 8$ & $3 \cdot 9$ \\
Valine & $36 \cdot 9$ & $42 \cdot 2$ & $44 \cdot 8$ & $46 \cdot 9$ & $48 \cdot 8$ & $4 \cdot 5$ \\
Isoleucine & $32 \cdot 4$ & $30 \cdot 0$ & $31 \cdot 7$ & $32 \cdot 3$ & $33 \cdot 7$ & $2 \cdot 9$ \\
Leucine & $46 \cdot 9^{\mathrm{a}, \mathrm{b}}$ & $42 \cdot 7^{\mathrm{b}}$ & $56 \cdot 5^{\mathrm{a}}$ & $53 \cdot 7^{\mathrm{a}, \mathrm{b}}$ & $58 \cdot 8^{\mathrm{a}}$ & $3 \cdot 5$ \\
Tyrosine & $26 \cdot 5$ & $23 \cdot 4$ & $26 \cdot 4$ & $25 \cdot 0$ & $23 \cdot 2$ & $2 \cdot 1$ \\
Phenylalanine & $25 \cdot 5$ & $28 \cdot 2$ & $21 \cdot 9$ & $24 \cdot 5$ & $23 \cdot 6$ & $2 \cdot 4$ \\
Histidine & $17 \cdot 3^{\mathrm{b}}$ & $15 \cdot 1^{\mathrm{b}}$ & $22 \cdot 6^{\mathrm{a}}$ & $22 \cdot 7^{\mathrm{a}}$ & $22 \cdot 3^{\mathrm{a}}$ & $1 \cdot 5$ \\
Lysine & $29 \cdot 1$ & $30 \cdot 7$ & $31 \cdot 8$ & $35 \cdot 4$ & $34 \cdot 1$ & $3 \cdot 5$ \\
Arginine & $30 \cdot 9^{\mathrm{a}}$ & $30 \cdot 0^{\mathrm{a}, \mathrm{b}}$ & $25 \cdot 8^{\mathrm{a}, \mathrm{b}}$ & $24 \cdot 6^{\mathrm{b}}$ & $23 \cdot 7^{\mathrm{b}}$ & $2 \cdot 1$ \\
Methionine & $11 \cdot 6$ & $13 \cdot 4$ & $11 \cdot 1$ & $15 \cdot 6$ & $11 \cdot 9$ & $1 \cdot 9$ \\
Cystine & $26 \cdot 4^{\mathrm{a}, \mathrm{b}}$ & $28 \cdot 6^{\mathrm{a}}$ & $24 \cdot 5^{\mathrm{a}, \mathrm{b}}$ & $22 \cdot 5^{\mathrm{a}, \mathrm{b}}$ & $20 \cdot 9^{\mathrm{b}}$ & $2 \cdot 4$ \\
\hline
\end{tabular}

${ }^{a, b, c}$ Mean values within a row with unlike superscript letters were significantly different $(P<0.05)$.

highest for glutamic acid, leucine and histidine (175 to $206 \%$ ) and moderate for aspartic acid, threonine, serine, glycine, alanine, valine, isoleucine, tyrosine and phenylalanine (73 to $140 \%)$. The increments were lowest for cystine $(51 \%)$ and proline $(26 \%)$.

The higher ileal endogenous AA flows in birds fed the EHC diets compared with those in birds fed the protein-free diet were consistent with previously published data in rats ${ }^{(11,14)}$, pigs $^{(10,15)}$ and chickens ${ }^{(13)}$. The values determined for ileal losses in $\mathrm{N}$ and AA determined for the protein-free diet and $200 \mathrm{~g} \mathrm{EHC} / \mathrm{kg}$ diet were within the ranges reported in the literature for growing chickens ${ }^{(12,13,24,25)}$.

The reasons for increased endogenous AA losses with increasing protein or peptide concentrations are not fully understood, but clearly these increases are related to increased output of one or more of the components of endogenous protein. Several possibilities may be proposed. First, increasing concentrations of dietary peptides or protein in the intestinal digesta may stimulate the secretion of endogenous enzymes. Studies with pigs have shown the increasing dietary protein levels to increase pancreatic ${ }^{(26)}$ and intestinal secretions ${ }^{(27)}$. Second, dietary protein or peptides may increase the secretion of mucin. It is also possible that the enhanced production of endogenous digestive enzymes may increase the hydrolysis of the mucus layer, releasing mucin into the digesta. Mariscal-Landing et al. ${ }^{(28)}$ reported that the ileal hexosamine excretion in pigs fed diets containing isolated soya protein increased when dietary crude protein concentration increased above $55 \mathrm{~g} / \mathrm{kg}$, suggesting a greater recovery of mucin at the terminal ileum. Another possibility is that, in addition to the direct protein effect, the EHC may contain bioactive peptides which may have specific effects in modifying the secretion of components of endogenous protein, including digestive enzymes and mucin. Partial hydrolysates of proteins have been shown to be potent stimulants of gastric acid and pancreatic secretions ${ }^{(29,30)}$. Of particular interest are the findings of Claustre et al. ${ }^{(31)}$ that enzymic hydrolysates of casein induced a strong mucin secretion in rat jejunum and this was attributed to the presence of an opioid peptide, $\beta$-casomorphin- 7 . In their study, mucin secretion was unaffected by native casein. Furthermore, given that increasing the dietary protein content from 100 to $250 \mathrm{~g} / \mathrm{kg}$ in diets based on guanidinated soyabean meal had no effect on ileal endogenous flow of lysine in pigs ${ }^{(16)}$, it is speculated that part of the increases in ileal endogenous AA flow with increasing EHC levels may be related to the presence of specific bioactive peptides in the casein hydrolysate. In the present study, AA that are found in high concentrations in pancreatic and intestinal secretions and mucin contributed in greater proportions to endogenous AA flow as dietary peptide concentrations increased, lending support to these possibilities. Pancreatic secretions are reported to have relatively high concentrations of branched-chain AA, glycine, aspartate and glutamate $^{(32,33)}$, whereas biliary secretions are known to be rich in glycine ${ }^{(34)}$. The predominance of threonine and serine in intestinal mucins is also known ${ }^{(35)}$. In the present study, increasing dietary peptide concentrations resulted in higher histidine flows. The reasons for this finding are not clear, since none of these individual sources are known to contain high concentrations of this AA.

It is noteworthy, however, that the flow of endogenous AA determined at the terminal ileum represents the proportion of endogenous secretions that are not digested and/or reabsorbed $^{(1)}$. The implication is that any factor that affects the reabsorption of AA of endogenous origin will also influence the estimates of endogenous AA flow. It is possible that the digestion and/or reabsorption of endogenous proteins may be down-regulated at higher peptide concentrations and this may have contributed, at least in part, to the higher flows determined at higher inclusion levels of EHC. For example, it has been suggested that the degradation of digestive enzymes may be lower in the presence of protein ${ }^{(36)}$, with dietary proteins protecting digestive enzymes from hydrolysis by being preferentially used as substrates. 
In the present study, an unusually higher flow of proline was determined in birds fed protein-free diets and proline dominated the AA profile of endogenous protein in the ileal digesta of these birds. Higher losses of proline have been previously reported in pigs fed protein-free diets ${ }^{(10,37)}$ and this finding was attributed to disturbances in protein metabolism. The present results lend support to this suggestion, as the ileal flow of proline was markedly lowered when peptides were included in the diet. It is likely that the disturbed protein metabolism may affect the losses of other AA as well, but these effects were not evident possibly because the absorption is still positive.

In agreement with previous data from chickens ${ }^{(12,13)}$ and pigs $^{(38,39)}$, glutamic acid, aspartic acid, threonine and glycine dominated the AA profile of endogenous protein in the ileal digesta. The impact of dietary protein or peptide concentrations on the composition of endogenous protein has not been previously reported. The ratios of most AA in the endogenous protein were unaffected when dietary EHC concentrations were increased from 50 to $200 \mathrm{~g} / \mathrm{kg}$. The exceptions were the proportions of proline and cystine which were found to decrease with increasing dietary EHC concentrations, while those of glutamic acid and histidine were greater at higher inclusions of EHC. While the effect on proline ratio is probably related to peptide alimentation, those on glutamic acid and cystine may be explained by changes in relative proportions of individual sources that contribute to the endogenous protein.

It is generally assumed that the AA composition of endogenous protein is reasonably constant ${ }^{(38,39)}$. Despite some changes in the AA profile of endogenous protein with increasing dietary peptide concentrations from 50 to $200 \mathrm{~g}$ $\mathrm{EHC} / \mathrm{kg}$, the present data are in general agreement with this assumption. A recent study by Cowieson \& Ravindran $^{(40)}$, however, found that the profile of endogenous protein was altered by the dietary addition of phytic acid. These findings suggest the need for further evaluation of the effect of dietary constituents on the AA composition of endogenous proteins.

When the EHC method is employed to determine ileal endogenous AA losses, the assumption is made that there are only small amounts of endogenous peptides in ileal digesta that are smaller than $10000 \mathrm{Da}$ in size. This assumption, however, has not been validated. It is expected that the concentration of these low-molecular-weight peptides at the terminal ileum will be low, but it is difficult to accurately quantify the amounts of these molecules and it is likely that such losses may lead to some underestimation of ileal endogenous AA flow. If this is valid, then it follows that such losses may have been relatively greater in animals fed diets containing higher peptide concentrations.

From a practical point of view, accurate estimates of endogenous AA values need to be obtained to improve the precision of true digestibility calculations and feed formulations. It is generally assumed that dietary protein intake has no effect on the ileal endogenous AA losses and the common practice is to use a constant value for endogenous AA flow in the calculations of true digestibility of feed ingredients, irrespective of their protein concentrations ${ }^{(41)}$. The present results suggest that the use of one set of values for endogenous correction of feedstuffs with varying protein concentrations is not valid. It appears therefore that, for the determination of true digestibility coefficients of feedstuffs, different endogenous corrections may have to be used depending on the protein concentrations of the assay diets, which typically range from $80 \mathrm{~g} / \mathrm{kg}$ for cereals to $180 \mathrm{~g} / \mathrm{kg}$ for protein sources $^{(42)}$.

In summary, the present data established that increasing dietary peptide concentrations have a dose-dependent effect on ileal endogenous AA flow in poultry. Such quantitative changes in endogenous AA flow will influence the maintenance requirements for $\mathrm{AA}$ and these changes must be taken into account in diet formulations. The increased endogenous AA losses with increasing dietary peptide concentrations may be explained by increased output of one or more of the components of endogenous protein. In this context, studies to investigate the effect of increasing dietary protein concentrations using guanidinated forms of purified proteins, such as casein, soya protein and wheat gluten, will be of interest. Further studies are also warranted to understand the mechanisms underlying the observed changes with dietary peptide concentrations.

\section{Acknowledgements}

The study was supported by the Monogastric Research Centre, Massey University. The authors declare that there was no conflict of interest in the present study. V. R. planned and was involved in the conduct of the study. P. C. H. M. was involved in the designing of the study and provided statistical support. S. M. R. was responsible for the laboratory analysis. D. V. T. was involved in the conduct of the study, and in the collection and processing of samples. The manuscript was written by V. R. and all authors contributed to the editing and improving of the final, submitted version.

\section{References}

1. Nyachoti CM, de Lange CFM, McBride BW \& Schulze H (1997) Significance of endogenous gut protein losses in the nutrition of growing pigs. Can J Anim Sci 77, 149-163.

2. Moughan PJ, Souffrant WB \& Hodgkinson SM (1998) Physiological approaches to determining gut endogenous amino acid flows in the mammal. Arch Anim Nutr 51, 237-252.

3. Sibbald IR (1987) Estimation of bioavailable AA in feedstuffs for poultry and pigs: a review with emphasis on balance experiments. Can J Anim Sci 67, 221-230.

4. Ravindran V \& Bryden WL (1999) Amino acid availability in poultry - in vitro and in vivo measurements. Aust J Agric Res 50, 889-908.

5. Ravindran V, Hew LI, Ravindran G \& Bryden WL (1999) A comparison of ileal digesta and excreta analysis for the determination of amino acid digestibility in feed ingredients for poultry. Br Poult Sci 40, 266-274.

6. Moughan PJ, Darragh AJ, Smith WC \& Butts CA (1990) Perchloric and trichloraacetic acids as precipitants of protein in endogenous ileal digesta from the rat. J Sci Food Agric 52, $13-21$.

7. Butts CA, Moughan PJ \& Smith WC (1991) Endogenous amino acid flow at the terminal ileum of the rat determined under conditions of peptide alimentation. J Sci Food Agric 55, 175-187.

8. Moughan PJ, Schuttert G \& Leenaars M (1992) Endogenous amino acid flow in the stomach and small intestine of the young growing pig. J Sci Food Agric 60, 437-442. 
9. Leterme P, Monmart T, Thewis A \& Morandi P (1996) Effect of oral and parenteral $\mathrm{N}$ nutrition vs $\mathrm{N}$-free nutrition on the endogenous amino acid flow at the ileum of the pig. $J$ Sci Food Agric 71, 265-271.

10. Hodgkinson SM, Moughan PJ, Reynolds GW \& James KAC (2000) The effect of dietary peptide concentration on endogenous ileal amino acid loss in the growing pigs. Br J Nutr 83, 421-430.

11. Donkoh A, Moughan PJ \& Morel PCH (1995) Comparison of methods to determine the endogenous amino acid flow at the terminal ileum of the growing rat. J Sci Food Agric 67, 359-366.

12. Ravindran V \& Hendriks WH (2004) Recovery and composition of endogenous protein collected at the terminal ileum as influenced by the age of broiler chickens. Aust J Agric Res 55, 705-709.

13. Ravindran V, Hew LI, Ravindran G \& Bryden WL (2004) Endogenous amino acid flow in the avian ileum: quantification using three techniques. Br J Nutr 92, 217-223.

14. Darragh AJ, Moughan PJ \& Smith WC (1990) The effect of amino acid and peptide alimentation on the determination of endogenous amino acid flow at the terminal ileum of the rat. J Sci Food Agric 51, 47-56.

15. Butts CA, Moughan PJ, Smith WC, Reynolds GW \& Garrick DJ (1993) The effect of food dry matter intake on endogenous ileal amino acid excretion determined under peptide alimentation in the $50 \mathrm{~kg}$ liveweight pig. J Sci Food Agric 62, 235-243.

16. Zhang HL, Qiao SY, Chen XJ, Wang X, Xing JJ \& Yin YL (2005) Effects of graded levels of soya-bean protein on endogenous ileal lysine loss and amino acid digestibility in growing pigs. Anim Sci 81, 257-264.

17. Ravindran V, Hew LI, Ravindran G \& Bryden WL (2005) Apparent ileal digestibility of AA in feed ingredients for broiler chickens. Anim Sci 81, 85-97.

18. Association of Official Analytical Chemists (1990) Official Methods of Analysis, 15th ed. Washington, DC: Association of Official Analytical Chemists.

19. Technicon (1973) Industrial Method no. 98/70w. Tarrytown, NY: Technicon.

20. Short FJ, Gorton P, Wiseman J \& Boorman KN (1996) Determination of titanium oxide added as an inert marker in chicken digestibility studies. Anim Feed Sci Technol 59, 215-221.

21. Moughan PJ, Schuttert G \& Leenaars M (1992) Endogenous amino acid flow in the stomach and small intestine of the young growing pig. J Sci Food Agric 60, 437-442.

22. Snedecor GW \& Cochran WG (1980) Statistical Methods, 7th ed. Ames, IA: Iowa State University Press.

23. SAS Institute, Inc (1997) SAS/STAT User's Guide Version 6.12 Cary, NC: SAS Institute, Inc.

24. Ravindran V \& Hendriks WH (2004) Recovery and composition of endogenous protein collected at the terminal ileum as influenced by the age of broiler chickens. Aust J Agric Res 55, 705-709.

25. Siriwan P, Bryden WL \& Annison EF (1994) Use of guanidinated dietary protein to measure losses of endogenous amino acids in poultry. $\mathrm{Br} J$ Nutr 71, 515-529.

26. Partridge IG, Low AG, Sambrook IE \& Corring T (1982) The influence of diet on the exocrine pancreatic secretion of growing pigs. Br J Nutr 48, 137-145.
27. Twomby J \& Meyer JH (1961) Endogenous nitrogen secretions into the digestive tract. $J$ Nutr 74, 453-460.

28. Mariscal-Landin G, Seve B, Colleaux Y \& Lebreton Y (1995) Endogenous amino acid nitrogen collected from pigs with end-to-end ileorectal anastomosis is affected by the method of estimation and altered by dietary fiber. J Nutr 125, $136-146$.

29. Hira T, Hara H \& Aoyama Y (1999) Stimulative effect of a casein hydrolysate on exocrine pancreatic secretion that is independent of luminal trypsin inhibitory activity in rats. Biosci Biotechnol Biochem 63, 1192-1196.

30. Matsuno K, Sasaki N \& Okabe S (2000) Gastric acid secretion in dogs in response to combinations of beer, ethanol and peptone meal - the role of endogenous gastrin. Aliment Pharmacol Ther 14, Suppl. 1, S109-S115.

31. Claustre J, Toumi F, Trompette A, Jourdan G, Guignard H, Chayvialle JA \& Plaisancie P (2002) Effects of peptides derived from dietary proteins on mucus secretion in rat jejunum. Am $J$ Physiol Gastrointest Liver Physiol 283, 521-528.

32. Corring T \& Jung $\mathbf{J}$ (1972) The amino acid composition of pig pancreatic juice. Nutr Rep Int 6, 187-190.

33. Gabert VM, Sauer WC, Li S \& Fan MZ (1996) Exocrine pancreatic secretions in young pigs fed diets containing fababeans (Vicia faba) and peas (Pisum sativum): concentrations and flows of total, protein-bound and free AA. J Sci Food Agric 70, 256-262.

34. Juste C (1982) Apports endogens pas les secretions digestive chez porc. In Physiologie Digestive chez le Porc, pp. 155-173 [JP Laplacw, T Corring and A Rerat, editors]. Paris: INRA.

35. Lien KA, Sauer WC \& He JM (2001) Dietary influences on the secretion into and degradation of mucin in the digestive tract of monogastric animals and humans. J Anim Feed Sci 10, 223-245.

36. Snook JT \& Meyer JH (1964) Response of digestive enzymes to dietary protein. J Nutr 82, 409-414.

37. de Lange CFM, Sauer WC \& Souffrant W (1989) The effect of protein status of the pig on the recovery and amino acid composition of endogenous protein in digesta collected from the distal ileum. J Anim Sci 67, 755-762.

38. Boison S \& Moughan PJ (1996) Dietary influences on endogenous ileal protein and amino acid losses in the pig - a review. Acta Agric Scand 46A, 154-164.

39. Pederson C \& Boison S (2002) Establishment of tabulated values for standardised ileal digestibility of crude protein and essential AA in common feedstuffs for pigs. Agric Scand 52A, $121-140$.

40. Cowieson AJ \& Ravindran V (2007) Effect of phytic acid and microbial phytase on the flow and amino acid composition of endogenous protein at the terminal ileum of growing broiler chickens. Br J Nutr 98, 745-752.

41. Lemme A, Ravindran V \& Bryden WL (2004) Ileal digestibility of amino acids in feed ingredients for broilers. World Poult Sci J 60, 421-435.

42. Ravindran V, Hew LI, Ravindran G \& Bryden WL (2005) Apparent ileal digestibility of amino acids in feed ingredients for broiler chickens. Anim Sci 81, 85-97. 